\title{
The Effect of Glufosinate Ammonium in Three Different Textured Soil Types under Malaysian Tropical Environment
}

(Kesan Glufosinat Ammonium pada Tiga Jenis Tanah Berbeza Tekstur dalam PersekitaranTropika Malaysia)

\author{
TAYEB M.A.,ISMAIL B.S. \& MARDIANA-JANSAR K.*
}

\begin{abstract}
Glufosinate ammonium is a broad spectrum, non-selective, contact and organophosphate herbicide which is commonly used in Malaysian oil palm plantations. Research area was one of the oil palm growing areas of Malaysia is located adjacent to the Tasik Chini, Pahang. Farmers use this herbicide to control several types of unwanted plants which could compete with the oil palm for nutrients. Rain water and the sprayed solution are easily adsorbed by soil particles. The glufosinate ammonium sorption was determined by the batch equilibrium technique. The collected soil samples $(0-50 \mathrm{~cm}$ depth) divided into five groups at $10 \mathrm{~cm}$ depth intervals. Glufosinate ammonium adsorption coefficients were correlated with the soil $\mathrm{pH}$, organic matter (OM), clay content, and cation exchange capacity (CEC). Series of glufosinate ammonium standard were as 0.01, 0.1, 0.25, 0.5, 1, 3, 5, and $10 \mu \mathrm{m} / \mathrm{mL}$. The Linear and Freundlich equations were fitted for obtaining the adsorption and desorption isotherms. The result of the analyses showed that adsorption of glufosinate ammonium was correlated to the clay content. The clay fraction of the soil is the main absorbent of the glufosinate ammonium. Desorption from the soil was indicated by the high binding strength of the adsorbed glufosinate ammonium.
\end{abstract}

Keywords: Adsorption; desorption; glufosinate ammonium; linear equation; sorption isotherm

\section{ABSTRAK}

Glufosinat ammonium adalah herbisid yang berspektrum luas, tidak memilih, jenis sentuhan dan di dalam kumpulan organofosfat yang sering digunakan dalam ladang kelapa sawit di Malaysia. Tapak kajian adalah di kawasan penanaman kelapa sawit yang terletak bersebelahan dengan Tasik Chini, Pahang. Petani menggunakan herbisid ini untuk mengawal beberapa jenis rumpai yang mengganggu tanaman dan boleh bersaing dengan pokok kelapa sawit untuk mendapatkan nutrien. Air hujan dan larutan herbisid mudah terserap oleh zarah tanah. Penjerapan glufosinat ammonium ditentukan oleh teknik keseimbangan berkelompok. Sampel tanah yang dikumpulkan (kedalaman 0-50 cm) dibahagikan kepada lima kumpulan pada jarak $10 \mathrm{~cm}$ kedalaman. Koefisien penjerapan ammonium glufosinat dikaitkan dengan pH tanah, bahan organik(OM), kandungan tanah liat, dan kapasiti pertukaran kation (CEC). Siri piawai amonium glufosinat ialah 0.01, 0.1, $0.25,0.5,1,3,5$ dan $10 \mu \mathrm{m} / \mathrm{mL}$. Persamaan Linear dan Freundlich dipasang untuk mendapatkan isoterma penjerapan dan penyahjerapan. Hasil analisis menunjukkan bahawa penjerapan amonium glufosinat dikaitkan dengan peratusan kandungan tanah liat. Sebahagian tanah liat tanah adalah penjerap utama glufosinat ammonium. Penyahjerapan daripada tanah ditunjukkan oleh kekuatan ikatan penjerapan glufosinat ammonium yang tinggi.

Kata kunci: Glufosinat ammonium; isoterma penjerapan; penjerapan; persamaan linear; penyahjerapan

\section{INTRODUCTION}

Different types of unwanted plants like woody perennial herbs, broad-leaved weeds and grasses are the main problem in oil palm plantations. Malaysia is the second largest palm oil exporting country in the world. Glufosinate ammonium is the most commonly used herbicide in the plantation sector (especially oil palm) to eradicate weeds and unwanted plants. In the 1980s glufosinate was introduced to the Malaysian pesticide market (Halimah et al. 2016; Ismail et al. 2015c, 2013). Currently more than 60 countries of the world use glufosinate ammonium which is registered under the names: Finale ${ }^{\circledR}$, Rely $^{\circledR}$, Challenge ${ }^{\circledR}$ and Basta ${ }^{\circledR}$. In Malaysia glufosinate ammonium is known under the trade name Basta ${ }^{\circledR}$.
The adsorption and desorption behaviour of the herbicide in soil can caused surface and ground water pollution. Many herbicides are strongly attached to soil particles because of their low solubility and high hydrophobicity (Ismail et al. 2015a; Tayeb et al. 2016; Zablotowicz et al. 2008). The adsorption/desorption or sorption of chemicals to the soil represents an important environmental process which affects the environmental fate of the chemicals. The migratory propensity of herbicides emphasizes the extent of herbicide sorption on environmental components such as soil, sediment, air and water. The leaching of herbicides through the soil column, photo-degradation, volatilization from soil and water as well as their concentration in natural water are essential 
information required to estimate the sorption data. The transport pathway and bio availability of herbicides depend on their adsorption characteristics. A problem occurred when a research confirmed that the goosegrass biotype was the first case whereby the development of multiple resistance across the three non-selective herbicides, namely glyphosate, glufosinate and paraquat (Chuah et al. 2018). Nonetheless, this problem made the farmer use the same herbicides in higher concentration with the purpose of killing the weeds.

Herbicide adsorption in a tropical environment decreases its concentration in aqueous solutions. Laboratory determination of the adsorption and desorption nature of herbicides is necessary for estimation of the potential hazards they pose to the environment, especially to surface and groundwater resources (Nagatomi et al. 2013; Screpanti et al. 2005). Studies on adsorption and desorption of herbicides in Malaysian tropical agricultural soils are relatively new and limited (Chang \& Liao 2002; Laitinen et al. 2008). Only a few studies on the persistence of glufosinate ammonium in Malaysian agricultural soils have been reported (Ismail et al. 2015b; Jariani et al. 2010). The present study aimed at reinforcing the content of existing literature and knowledge.

\section{MATERIALS AND METHODS}

\section{CHEMICALS AND REAGENTS}

The glufosinate ammonium standard was obtained from Dr. Ehrenstorfer (GmbH Germany). The basic properties and chemical structure of GLUF are shown in Table 1 and Figure 1, respectively.

HPLC grade acetone, acetonitrile and diethyl ether were purchased from Merck (Darmstadt, Germany). The analytical grade reagents such as potassium dihydrogenphosphate $\left(\mathrm{KH}_{2} \mathrm{PO}_{4}\right)$, potassium hydroxide $(\mathrm{KOH})$, disodium tetraborate decahydrate $\left(\mathrm{N}_{2} \mathrm{~B}_{4} \mathrm{O}_{7} \cdot 10 \mathrm{H}_{2} \mathrm{O}\right)$, 9-Fluorenylmethyl Chloroformate (FMOC-Cl) and hydrochloric acid (HCL, 37.9\%) were purchased from sigma Aldrich. The standard stock solution of glufosinate ammonium $(200 \mu \mathrm{g} / \mathrm{mL})$ made up of ultra-pure water and
$0.01 \mathrm{M}$ FMOC-Cl was prepared in acetone. Acetone, $0.125 \mathrm{M}$ borate buffer solution \& $0.01 \mathrm{M}$ FMOC-Cl were used for the pre column derivatization.

\section{COLLECTION OF SOIL SAMPLES}

The collected soil samples represented the soil types of the Tasik Chini oil palm plantation. The soil samples were collected randomly from different locations at five soil depths of 10, 20,30, 40, and $50 \mathrm{~cm}$. Air dried soils were sieved by a $2 \mathrm{~mm}$ sieve. The Pipette Method (Day 1965) was used for soil texture determination. The soil textural class was determined using the Calgon dispersing agent and the USAD soil textural triangle. Soil CEC was determined by the leaching method (Method 9080) (EPA 1986). The Walkley and Black Method was used for soil organic carbon (OC) determination. Organic carbon of the soils was determined by the Walker-Black method (Allison 1965). The Blackman Digital $\mathrm{pH}$ meter was used to measure soil $\mathrm{pH}$ from the soil water suspensions $(1: 1 \mathrm{v} / \mathrm{v})$. The clay mineral content was analysed using the X-ray diffraction technique (XRD) (Figure 2).

The physico-chemical properties of collected soil samples were shown in Table 2. The clay loam soil texture contains high organic matter than other two soil texture. Clay soil contains highest CEC (14.79).

\section{ADSORPTION AND DESORPTION EXPERIMENTS}

The batch equilibrium technique was used for sorption isotherms as it permitted convenient evalution of the parameters that influenced the sorption process (OECD 2000). The analyses were completed using 7 different concentrations of the supplied glufosinate ammonium standard and they were done in triplicate. Sieved soil (2 gm) was transferred into $50 \mathrm{~mL}$ polypropylene tubes. Then, 20 $\mathrm{mL}$ solution containing $0.25,0.5,1,3,5,7$, and $10 \mu \mathrm{g} / \mathrm{mL}$ of glufosinate ammonium standard were added in the same tube. At room temperature, the tubes were equilibrated for 24 h. After equilibration, the tubes were centrifuged for $20 \mathrm{~min}$ at $3000 \mathrm{rpm}$. Equilibrium concentration of the supernatant was determined by HPLC-FLD. The adsorption isotherm was fitted to the Linear and Freundlich equations and expressed

TABLE 1. Features of glufosinate ammonium

\begin{tabular}{cccc}
\hline Chemical structure & Molar mass & Water solubility & Dissociation constant $\left(\mathrm{P}^{\mathrm{Ka}}\right)$ \\
\hline $\mathrm{C}_{5} \mathrm{H}_{15} \mathrm{~N}_{2} \mathrm{O}_{4} \mathrm{P}$ & 198.19 & $>500 \mathrm{~g} / \mathrm{L}$ at $20^{\circ} \mathrm{C}$ & $9.15 \pm 0.07$ \\
\hline
\end{tabular}<smiles>CP(=O)(O)CCC(N)C(=O)O[CH+]N</smiles>

(Reference: http://www.chemicalbook.com/Chemical product Property CB2697882)

FIGURE 1. Structural formula of glufosinate ammonium 


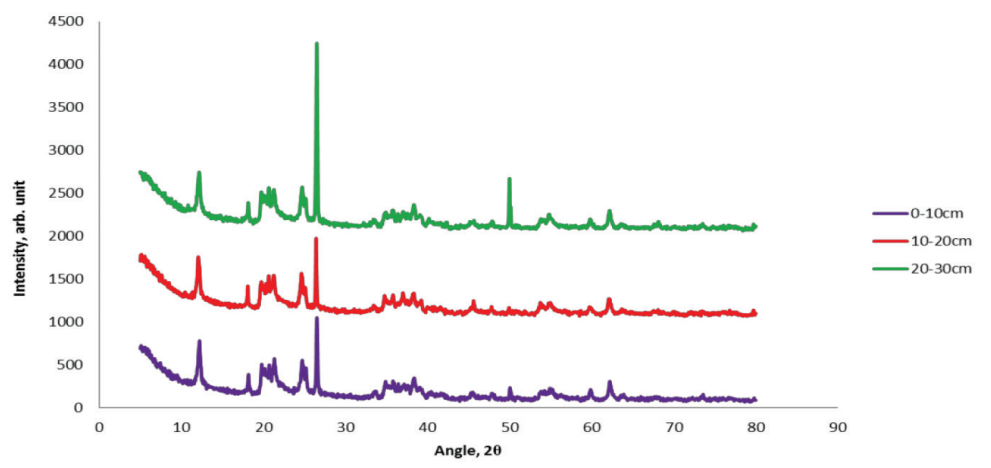

FIGURE 2. Soil mineral content as determined XRD

TABLE 2. Average soil characteristics in the study area

\begin{tabular}{lccccc}
\hline Soil texture & $\mathrm{pH}$ & $\begin{array}{c}\text { Organic matter } \\
(\%)\end{array}$ & $\begin{array}{c}\text { Organic carbon } \\
(\%)\end{array}$ & $\begin{array}{c}\text { Cation exchange capacity } \\
(\mathrm{cmol} / \mathrm{kg})\end{array}$ & $\begin{array}{c}\text { Bulk } \\
\text { density }\end{array}$ \\
\hline Clay & 4.20 & 3.53 & 2.41 & 14.79 & 1.08 \\
Silty clay & 4.24 & 3.58 & 2.55 & 9.54 & 1.13 \\
Clay loam & 4.33 & 4.67 & 3.38 & 5.67 & 1.20 \\
\hline
\end{tabular}

as follows $C s=\log K f+{ }^{1}{ }_{n f} \log C e$. Adsorbed herbicide $C s$, $\mu g / g$ and adsorption difference were $\mu g / L$ were calculated. After the adsorption experiment, desorption determination was done immediately.

\section{DERIVATIZATION AND HPLC ANALYSIS}

The clear supernatant solutions were subjected to pre column derivatization before the HPLC analysis was done. One (1) mL supernatant was derivatized by $0.125 \mathrm{M}$ borate buffer at $0.8 \mathrm{~mL}$, acetone, $0.8 \mathrm{~mL}$ and $0.01 \mathrm{M}$ FMOC-Cl. The supernatant was swirled 30 seconds and left on the table for $30 \mathrm{~min}$ for chemical reactions to take place. The procedure was done in room temperature. After $30 \mathrm{~min}$, the sample was washed with $1 \mathrm{mLDiethyl} \mathrm{ether} \mathrm{to} \mathrm{remove}$ the excess of FMOC-Cl and then placed on a plane surface until two layers formed (Ibanez et al. 2005; Sancho et al. 1994). After formation of the two layers, a $1 \mathrm{~mL}$ sample was carefully collected from the bottom layer and filtered using a $0.25 \mu \mathrm{m}$ syringe filter. The filtered sample was analysed using the HPLC - Fluorescence detector (FLD). (The FLD $\lambda$ ex $=263 \mathrm{~nm} \& \lambda$ em $=310 \mathrm{~nm}$. The HPLC was Agilent 1220 infinity LC and the analytical column was EC 250/3 NUCLEODUR $C_{18}$ Gravity, $5 \mu \mathrm{m}$ with gradient system). The mobile phase used was Acetonitrile: $0.2 \%$ phosphoric acid solution (35:65). The mobile phase $\mathrm{pH}$ was maintained by using $2 \mathrm{M} \mathrm{KOH}$ and $1 \mathrm{M} \mathrm{HCL}$. The derivatization process is shown in Figure 3.

\section{RESULTS AND DISCUSSION}

\section{GLUFOSINATE AMMONIUM STANDARD CALIBRATION CURVE}

Figure 4(a) shows that the linear regression (r2) obtained was 0.99 . The correlation equation $\mathrm{Y}=239.44 \mathrm{x}+5.21$

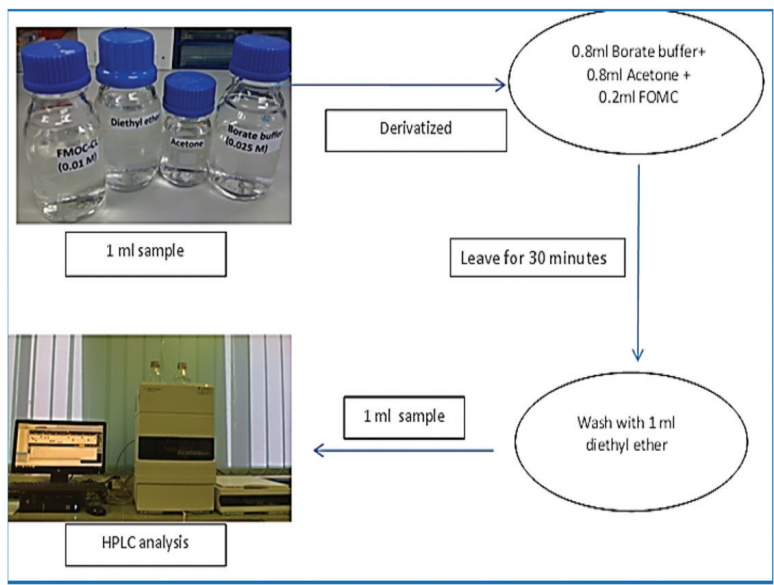

FIGURE 3. Derivatization process of glufosinate ammonium 
was prepared using the calibration data, where $\mathrm{X}$ and $\mathrm{Y}$ represented the concentration $\left(\mu \mathrm{g} \mathrm{mL}^{-1}\right)$ and area of glufosinate ammonium. The retention time (5.855) of glufosinate ammonium standard is shown in Figure 4(b).

The chromatogram of the herbicide glufosinate ammonium was obtained during analysis of the calibration curve. For better recovery, the detector wavelengths were monitored as $\lambda_{\mathrm{em}} / \lambda_{\mathrm{em}} 260 / 310,263 / 317,265 / 317,267 / 320$ and $270 / 320$. Based on the peak height and area it was observed that the maximum absorbance and best selectivity peak of glufosinate ammonium was at detector $\lambda_{\mathrm{ex}}=263$ $\mathrm{nm} / \lambda_{\mathrm{em}}=317 \mathrm{~nm}$ wavelength. The minimum detection limit was $0.001 \mu \mathrm{g} \mathrm{mL} \mathrm{m}^{-1}$.

\section{ADSORPTION EQUILIBRIUM TIME}

With reference to clay particles, glufosinate ammonium was more strongly adsorbed to silty clay and clay loam particles as shown in Figure 5. The adsorption to silty clay and clay loam was 1.5 times higher than the adsorption to organic matter (Druart et al. 2011). The glufosinate ammonium adsorption to clay loam and silty clay particles became very slow and constant after it reached the equilibrium position among the soil particles and supernatant. After shaking for $3 \mathrm{~h}$, the equilibrium position was achieved. At the initial stage herbicide adsorbed the outer surface of soil particle. Electrostatic binding played an important role in glufosinate ammonium sorption process (Ismail et al. 2015b). Internal surface diffusion and external surface depletion was the reason for decreased sorption at the later stage (Yun et al. 2014). The percentage glufosinate ammonium adsorbed on to the soil particles after $3 \mathrm{~h}$ was more than $90 \%$ for all the three types of soil tested. A similar result to the glufosinate ammonium adsorption patterns was found (Allen-King et al. 1995; Yun et al. 2014). The adsorptive equilibrium of glufosinate ammonium was attained within 75 to $100 \mathrm{~min}$ in the clay type soils. The result is supported by that of Accinelli et al. (2004). The earlier mentioned studies reported that glufosinate ammonium has similar equilibrium time in different soil types and it ranged from 45 to $180 \mathrm{~min}$.

\section{SOIL pH EFFECT ON ADSORPTION}

Glufosinate ammonium adsorption on the previously mentioned soil types were affected by soil $\mathrm{pH}$. Three $\mathrm{pH}$ numbers $(2,7 \& 11)$ were investigated in this experiment. It was observed that the adsorption of glufosinate

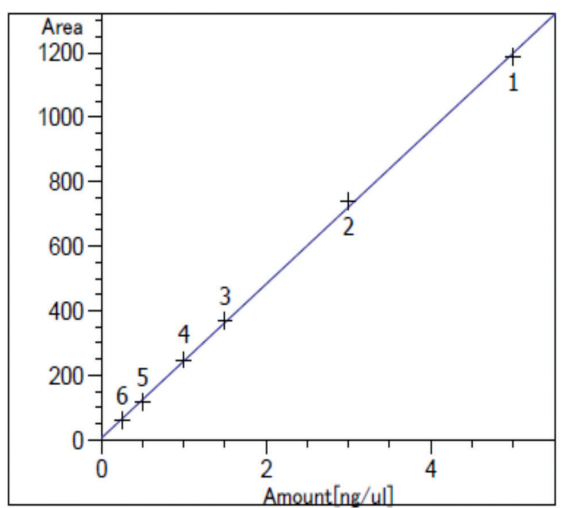

GLUF at exp. RT: 5.731

FLD1 A, Ex=270, Em=315

Correlation: $\quad 0.999^{\circ}$

Residual std. Dev.: 11.3231

Formula: $y=m x+b$

m: $\quad 239.44324$

b: $\quad 5.21077$

$\mathrm{x}$ : Amount

y: Area

(a)

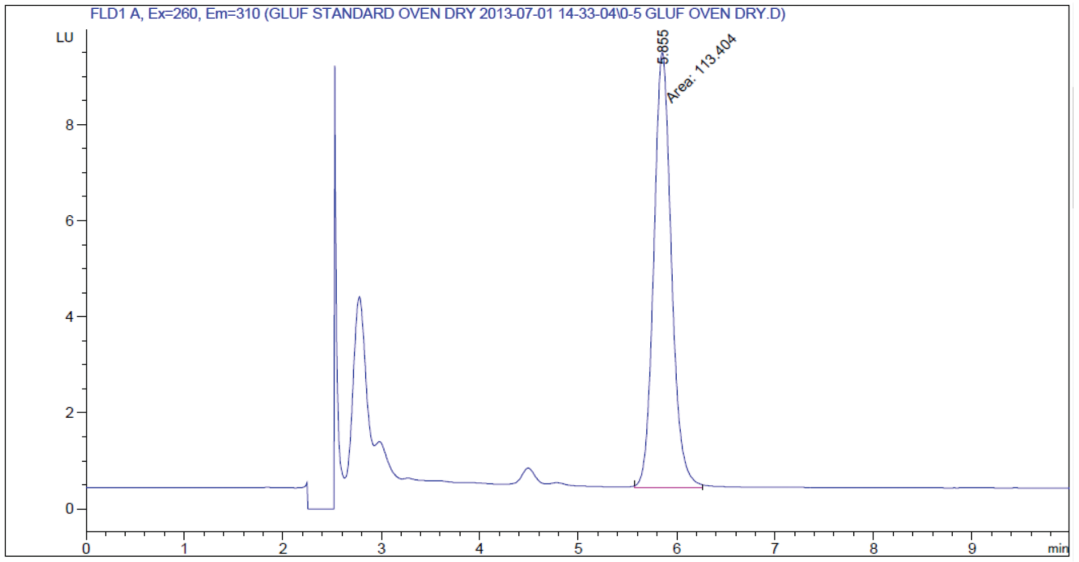

(b)

FIGURE 4. (a) Linear regression of glufosinate ammonium standard (HPLC-FLD) and b) Chromatogram of glufosinate ammonium standard (generated by HPLC-FLD) during analysis of the calibration curve at $0.25 \mu \mathrm{gmL}^{-1}$ concentration 


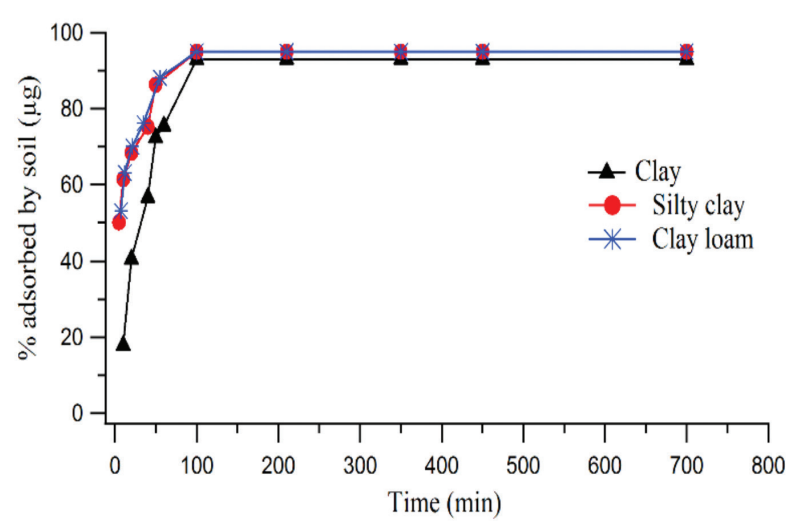

FIGURE 5. Adsorption equilibrium of glufosinate ammonium in clay, silty clay, clay loam soils of Tasik Chini

ammonium was highest at higher $\mathrm{pH}$ levels, for the three soil types, (the results are supported by Gerhartz \& Markus 2010). At pH11, the adsorption percentages of glufosinate ammonium adsorbed on to the clay, silty clay and clay loam soils were $91.37,92.4$, and $92.9 \%$, respectively, while, at $\mathrm{pH} 2$, the adsorption percentages were not more than $84.12 \%$ for the three soil types. The statistical analysis, ANOVA (analysis of variance) showed a significant effect of $\mathrm{pH}(\mathrm{P} \leq 0.05)$ on glufosinate ammonium adsorption on the three soil types. Among the three soil types glufosinate ammonium adsorption was slightly higher on the silty clay and clay loam soils compared to that on the clay textured soil.

Glufosinate ammonium adsorption increased with the increase of $\mathrm{pH}$ and the number of negative charges. The number of negative charges increased because of $\mathrm{H}^{+}$ ion loss from the clay particle surface. The clay particle surface displayed negative charges $(\mathrm{pH}>2.0)$ on account of $\mathrm{pH}$-dependent surface hydroxyl groups of variable charges. When the $\mathrm{pH}$ increased, the negative charges also increased, and this result is compatible with the findings of the study where adsorbed amounts were reported to be dependent on increase in $\mathrm{pH}$ (Corbett et al. 2004; Tayeb et al. 2015). These observations are in agreement with those of Tsuji et al. (1997), where it was reported that at high $\mathrm{pH}$, glufosinate ammonium was strongly adsorbed to clay particles in the soil.
When soil $\mathrm{pH}$ decreases, the value of the adsorption coefficient $K_{d}$ also decreases. This is compatible with studied soil $\mathrm{pH}$ have an effect on sorption. The distribution coefficient $K_{d}$, which is empirically derived, decreases when $\mathrm{pH}$ decreases. High $K_{d}$ value indicated strong bonding of glufosinate ammonium with soil particle.

\section{EFFECT OF TEMPERATURE ON ADSORPTION}

Temperature has a significant effect on adsorption by soils through its effect on solubility, and this adsorption has been shown for parathion by Behrendt et al. (1990) as well as for atrazine (Dinehart et al. 2009; Ismail et al. 2015d). Druart et al. (2011) explored the dissimilarity in the adsorption mechanisms of the protonated and ionized forms of pentachlorophenol (PCP) by standardizing their adsorption coefficients at three different temperatures $\left(4^{\circ} \mathrm{C}, 25^{\circ} \mathrm{C}\right.$ and $\left.55^{\circ} \mathrm{C}\right)$. In the case of the neutral form, a trend was observed whereby there was at decrease in $K_{d}$ with increasing temperature (Kah \& Brown 2006). Tseng et al. (2004) observed that the $K_{d}$ value increased for chlorosulfuron when the temperature decreased from $30^{\circ} \mathrm{C}$ to $10^{\circ} \mathrm{C}$. In the present study, clay, silty clay and clay loam soils sorption coefficient, $K_{o c}$ and $K_{f}$ decreased with rise in temperature from $30^{\circ} \mathrm{C}$ to $40^{\circ} \mathrm{C}$, probably due to the effect of temperature on the weak binding between glufosinate ammonium and the soil particles (Table 3). A similar behavior was observed for glufosinate ammonium on the same soils. Temperature had an exiguous effect on adsorption. The total percentage glufosinate ammonium adsorbed on the three mentioned soil types was significant $(\mathrm{P} \leq 0.05)$ when temperature increased from $30^{\circ} \mathrm{C}$ to $40^{\circ} \mathrm{C}$. These results are supported by those of the previous reports (Goodwin et al. 2003; Qian et al. 2011; You \& Barker 2004, 2002).

Glufosinate ammonium was strongly adsorbed and inactivated by the soil clay particles. It averted the build-up of the active surface when it came into close contact with the soil particles. The glufosinate ammonium positive charge was strongly drawn to the negative charge of soil clay particles (Gallina \& Stephenson 1992; Ismail et al. 2015e; Tebbe \& Reber 1991).

TABLE 3. Sorption coefficient $K_{d}, K_{o c}$ and $K_{f}$ of three soil texture at 30,35 and $40^{\circ} \mathrm{C}$ for glufosinate ammonium

\begin{tabular}{lcccc}
\hline Soil & Temperature $\left({ }^{\circ} \mathrm{C}\right)$ & $K_{d}$ & $K_{o c}$ & $K_{f}$ \\
\hline Clay & 30 & 1265.32 & 25.89 & 10.12 \\
& 35 & 1000.79 & 20.88 & 4.99 \\
\multirow{3}{*}{ Silty clay } & 40 & 439.21 & 9.08 & 1.23 \\
& 30 & 892.31 & 51.12 & 16.77 \\
& 35 & 470.26 & 469.98 & 5.98 \\
Clay loam & 40 & 320.05 & 319.54 & 2.33 \\
& 30 & 893.45 & 51.60 & 16.89 \\
& 35 & 471.11 & 26.67 & 6.23 \\
& 40 & 320.61 & 17.57 & 2.45 \\
\hline
\end{tabular}




\section{EFFECT OF HERBICIDE CONCENTRATION ON ADSORPTION}

Table 4 shows the glufosinate ammonium adsorption at different concentrations ranging from $0.10 .5 \mathrm{ug} \mathrm{g}^{-1}$ in three different soil types. In clay $6.29,13.25,30.11,53.45$, 158.33 and $265.05{\mu g g^{-1}}$ glufosinate ammonium were adsorbed; in silty clay soil 6.62, 13.43, 30.67, 53.72, 158.87 and $265.25 \mathrm{\mu gg}^{-1}$ glufosinate ammonium were adsorbed. In clay loam 6.71, 13.97, 30.82, 53.59, 158.95, $265.25{\mu \mathrm{gg}^{-1}}^{-1}$ glufosinate ammonium were adsorbed. The concentrations used were $0.1,0.3,0.5,1,3$ and $5 \mu \mathrm{gmL}^{-1}$, respectively. The adsorption results for the above three types of soils showed no significant difference. The sequences of the studied soils were as follows: clay loam $>$ silty clay $>$ clay for the samples analyzed (in triplicate). The analysis of variance (ANOVA) showed that glufosinate ammonium adsorption was significantly affected $(\mathrm{P}<0.05)$ by the different concentrations in the three types of soil. These results were supported by those of Qian et al. (2011). Shin et al. (2011) used XRD crystallography for analyzing the clay fractions that contained adsorbed glufosinate ammonium.

The binding strength of glufosinate ammonium with soil particles is attributed to the soil adsorption coefficient $K_{d}$. Glufosinate ammonium adsorption to clay soil $\left(r^{2}=\right.$ $0.988)$, silty clay $\left(r^{2}=0.895\right)$ and clay loam $\left(r^{2}=0.893\right)$, was obtained using the Freundlich adsorption isotherm as in Figure 6(a), 6(b) \& 6(c). The $K_{f} \& K_{d}$ values of the three types of soil were as follows: $382.87,881.42 \mathrm{Lkg}^{-1} ; 366.10$; $911.05 \mathrm{Lkg}^{-1}$, and $359.98,924.10 \mathrm{Lkg}^{-1}$; the $1 / n$ values were $1.32,1.41$ and 1.48 (Table 5). The $1 / n$ values for the three
TABLE 4. Glufosinate ammonium adsorption $\%$ in three different textured soils $(n=5)$

\begin{tabular}{lcc}
\hline Soil type & $\begin{array}{c}\text { Initial amount } \\
\left(\mu g \mathrm{gL}^{-1}\right)\end{array}$ & $\begin{array}{c}\text { Amount absorbed } \\
\left(\mu g^{-1}\right)\end{array}$ \\
\hline Clay & 0.1 & $6.29( \pm 0.05)$ \\
& 0.3 & $13.25( \pm 0.21)$ \\
0.5 & $30.11( \pm 0.02)$ \\
& 1 & $53.45( \pm 0.01)$ \\
& 3 & $158.33( \pm 0.05)$ \\
Silty clay & 5 & $265.05( \pm 0.03)$ \\
& 0.1 & $6.62( \pm 0.01)$ \\
& 0.3 & $13.43( \pm 0.04)$ \\
& 0.5 & $30.67( \pm 0.05)$ \\
& 1 & $53.72( \pm 0.03)$ \\
& 3 & $158.87( \pm 0.02)$ \\
& 5 & $265.25( \pm 0.01)$ \\
& 0.1 & $6.71( \pm 0.05)$ \\
& 0.3 & $13.97( \pm 0.03)$ \\
& 0.5 & $30.82( \pm 0.01)$ \\
& 1 & $53.59( \pm 0.01)$ \\
& 3 & $158.95( \pm 0.04)$ \\
& 5 & $265.25( \pm 0.03)$ \\
\hline
\end{tabular}

types of soil were quite similar, indicating that increasing the solution concentration resulted in increased adsorption of the compound. The results showed high adsorption of the glufosinate ammonium onto the three soil types (Yun et al. 2014). Glufosinate ammonium adsorbs easily to

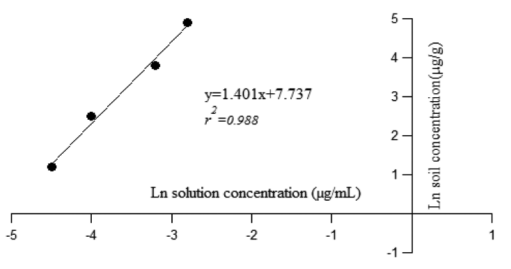

(a)

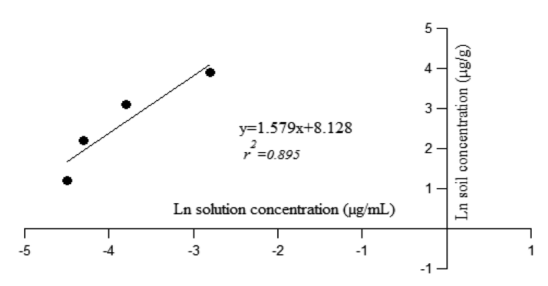

(b)

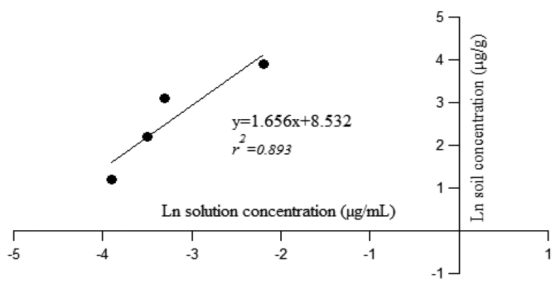

(c)

FIGURE 6. Glufosinate ammonium adsorption in (a) clay soil, (b) silty clay soil and (c) clay loam soil

TABLE 5. Percentage OM and $K_{d^{\prime}} K_{f}, 1 / n$ values for the adsorption of glufosinate ammonium in soils

\begin{tabular}{lccccc}
\hline Soil Type & $\% O M$ & $r^{2}$ & $K_{f}$ & $1 / n$ & $K_{d}$ \\
\hline Clay & 2.13 & 0.988 & 382.87 & 1.3 & 881.42 \\
Silty clay & 4.05 & 0.895 & 366.10 & 1.4 & 911.05 \\
Clay loam & 4.22 & 0.893 & 359.98 & 1.4 & 924.10 \\
\hline
\end{tabular}


the negatively charged soil particles. The mechanism of glufosinate ammonium adsorption is charge transfer ionic bonds (Druart et al. 2011). The soil sorption coefficient $K_{d}$ value was correlated with soil properties such as soil organic carbon $\left(K_{o c}\right)$ (Weber et al. 2004). The $\left(K_{o c}\right)$ value is not useful, when the ionic herbicide glufosinate ammonium binds with soil particles by electrostatic mechanisms involving soil mineral and organic matter (OM).

\section{CONCLUSION}

The herbicide adsorption process binds glufosinate ammonium with clay particles in a manner similar to that of iron fillings getting attached to a magnet. Experimental studies were carried out to investigate the soil $\mathrm{pH}$, temperature and glufosinate ammonium concentration of its sorption behaviour on three selected soil texture. The adsorption behavior of glufosinate ammonium under the Malaysian tropical environment showed that it could be modeled well by the Freundlich isotherm. Glufosinate ammonium adsorption was found to be affected by temperature, and adsorption capacity significantly increased as the temperature was reduced. However, results demonstrated that the total amount of glufosinate ammonium adsorption onto the three mentioned soils was not significant ( $\mathrm{p} \leq 0.05$ ). Glufosinate ammonium remained stable in the soil samples up to 2 months when stored at $-20^{\circ} \mathrm{C}$. However, due to the high adsorption and low desorption tendency, the potential environmental risk connected with glufosinate ammonium movement from the soil column to ground water would be minimal.

\section{ACKNOWLEDGEMENTS}

This study was supported by the research grant no. AP2014-009 and GUP-2014-087 from Universiti Kebangsaan Malaysia and the Ministry of Higher Education (MOHE), Malaysia.

\section{REFERENCES}

Accinelli, C., Crepanti, C., Vicari, A. \& Catizone, P. 2004. Influence of insecticidal toxins from Bacillus thuringiensis subsp. kurstaki on the degradation of glyphosate and glufosinate-ammonium in soil samples. Agric. Ecosyst. Environ. 103(3): 497-507.

Allen-King, R.M., Butler, B.J. \& Reichert, B. 1995. Fate of the herbicide glufosinate-ammonium in the sandy, low-organiccarbon aquifer at CFB Borden, Ontario, Canada. J. Contam. Hydrol. 18(2): 161-179.

Allison, L.E. 1965. Organic carbon. In Methods of Soil Analysis Part 2, edited by Black, C.A. Wisconsin: American Society of Agronomy. p. 1367.

Behrendt, H., Matthies, M., Gildemeister, H. \& Görlitz, G. 1990. Leaching and trans-formation of glufosinate-ammonium and its main metabolite in a layered soil column. Environ. Toxicol. Chem. 9(5): 541-549.

Chang, S.Y. \& Liao, C.H. 2002. Analysis of glyphosate, glufosinate and aminomethylphosphonic acid by capillary electrophoresis with indirect florescence detection. $J$. Chromatogr. A 959(1-2): 309-315.
Chuah Tse Seng, Lim Win Kent \& Ismail B.S. 2018. Potential of oil palm frond residues in combination with s-metolachlor for the inhibition of selected herbicide-resistant biotypes of goosegrass emergence and seedling growth. Sains Malaysiana 47(4): 671-682.

Corbett, J.L., Askew, D., Thomas, W.E. \& Wilcut, J.W. 2004. Weed efficacy evaluations for bromoxynil, glufosinate, glyphosate, pyrithiobac, and sulfosate. Weed Technol. 18(2): 443-453.

Dinehart, S.K., Smith, L.M., McMurry, S.T., Anderson, T.A., Smith, P.N. \& Haukos, D.A. 2009. Toxicity of a glufosinateand several glyphosate-based herbicides to juvenile amphibians from the southern High Plains, USA. Sci. Total Environ. 407(3): 1065-1071.

Druart, C., Delhomme, O., Vaufleury, A., Ntcho, E. \& Millet, M. 2011. Optimization of extraction procedure and chromatographic separation of glyphosate, glufosinate and aminomethylphosphonic acid in soil. Anal. Bioanal. Chem. 39(4): 1725-1732.

EPA. 1986. Method 9080, Cation-exchange capacity of soils (ammonium acetate). www3.epa.gov/epawaste/hazard/ testmethods/sw846/pdfs/9080.pdf.

Gallina, M.A. \& Stephenson, G.R. 1992. Dissipation of [14C] glufosinate-ammonium in two Ontario soils. J.Agric. Food Chem. 40(1): 165-168.

Gerhartz, M. \& Markus, K. 2010. Enrichment and low-level determination of glyphosate, aminomethylphosphonic acid and glufosinate in drinking water after clean up by cation exchange resin. J. Sep. Sci. 33(8): 1139-1146.

Goodwin, L., Startin, J.R., Goodall, D.M. \& Keely, B.J. 2003. Tandem mass spectrometric analysis of glyphosate, glufosinate, aminomethylphosphonic acid and methylphosphinicopropionic acid. Rapid Commun. Mass Spectrom. 17(9): 963-969.

Halimah, M., Tan, Y.A., Ismail, B.S. \& Tayeb, M.A. 2016. Dissipation of fluroxypyr in a Malaysian agricultural soil with simulation using the persist and Varleach Model. J. Oil Palm Res. 28(1): 26-33.

Ibanez, M., Pozo, O.J., Ancho, J.V., Lopez, F.J. \& Hernandez, F. 2005. Residue determination of glyphosate, glufosinate and aminomethylphosphonic acid in water and soil samples by liquid chromatography coupled to electrospray tandem mass spectrometry. J. Chromatogr. A 1081(2): 145-155.

Ismail, B.S., Choo, L.Y., Salmijah, S., Halimah, M. \& Tayeb, M.A. 2015a. Adsorption, desorption and mobility of cyfluthrin in three Malaysian tropical soils of different textures. J. Environ. Biol. 36(5): 1105-1111.

Ismail, B.S., Mazlinda, M. \& Tayeb, M.A. 2015b. The persistence of Deltamethrin Malaysian agricultural soils. Sains Malaysiana 44(1): 83-89.

Ismail, B.S., Ooi, E.K. \& Tayeb, M.A. 2015c. Degradation of triazine-2- ${ }^{14} \mathrm{C}$ metsulfuron-methyl in soil from an oil palm plantation. PLOS ONE 10(10): e0138170.

Ismail, B.S., Prayithno \& Tayeb, M.A. 2015d. Contamination of rice field water with sulfonylurea and phenoxy herbicides in the Muda Irrigation Scheme, Kedah, Malaysia. J. Environ. Monit. Assess. 187: 406.

Ismail, B.S., Eng, O.K. \& Tayeb, M.A. 2015e. Laboratory assessment of 14c-PhenylMetsulfuron-Methyl degradation in an oil palm plantation soil. J. Oil Palm Res. 27(4): 403-416.

Ismail, B.S., Mazlinda, M. \& Tayeb, M.A. 2013. Adsorption, desorption and mobility of Cypermethrin and Deltamethrin in Malaysian soils. Int. J. Plant Animal Environ. Sci. 3(4): 23-29. 
Jariani, S.M.J., Rosenani, A.B., Samsuri, A.W., Shukor, A.J. \& Ainie, H.K., 2010. Adsorption and desorption of glufosinate ammoniumin soils cultivated with oil palm in Malaysia. Malaysian J. Soil Sci. 14: 41-52.

Kah, M. \& Brown, C.D. 2006. Adsorption of ionisable pesticides in soils. Reviews of Environmental Contamination and Toxicology 188: 149-217.

Laitinen, P., Siimes, K.S., Ramo, L., Jauhiainen, L., Eronen, L., Oinonen, S. \& Hartikainen, H. 2008. Effect of soil phosphorus status on environmental risk assessment of glyphosate and glufosinate ammonium. J. Environ. Qual. 37(3): 830-838.

Nagatomi, Y., Yoshioka, T., Yanagisawa, M., Uyama, A. \& Mochizuki, N. 2013. Simultaneous LC-MS/MS analysis of glyphosate, glufosinate, and their metabolic products in beer, barley tea, and their ingredients. Biosci. Biotechnol. Biochem. 77(11): 2218-2221.

Qian, K., He, S., Tang, T., Shi, T., Li, J. \& Cao, Y. 2011. A rapid liquid chromatography method for determination of glufosinate residue in maize after derivatisation. Food Chem. 127(2): 722-726.

Sancho, J., Hernández, V.F., López, F.J., Hogendoorn, E.A., Dijkman, E. \& Zoonen, P.V. 1996. Rapid determination of glufosinate, glyphosate and aminomethylphosphonic acid in environmental water samples using precolumn fluorogenic labeling and coupled-column liquid chromatography. $J$. Chromatogr. A 737(1): 75-83.

Screpanti, C., Accinelli, C., Vicari, A. \& Catizone, P. 2005. Glyphosate and glufosinate-ammonium runoff from a corngrowing area in Italy. Agron. Sustain. Dev. 25: 407-412.

Shin, J.S., Kim, K.M., Lee, D.J., Lee, S.B., Burgos, N.R. \& Kuk, Y.I. 2011. Resistance levels and fitness of glufosinate-resistant transgenic sweet potato in field experiments. Field Crops Research 121(3): 324-332.

Tayeb, M.A., Ismail, B.S., Jansar-Mardiana, K. \& Goh Choo Ta. 2016. Troubleshooting and maintenance of high-performance liquid chromatography during herbicide analysis: An overview. Sains Malaysiana 45(2): 237-245.

Tayeb, M.A., Ismail, B.S. \& Mardiana-Jansar, K. 2015. Comparison of four different solid phase extraction cartridges for sample clean-up in the analysis of glufosinate ammonium from aqueous samples. Int. J. ChemTech. Res. 7(6): 26122619.
Tebbe, C.C. \& Reber, H.H. 1991. Degradation of $\left[{ }^{14} \mathrm{C}\right]$ phosphinothricin (glufosinate) in soil under laboratory conditions: Effects of concentration and soil amendments on ${ }^{14} \mathrm{CO}_{2}$ production. Biol. Fertil. Soils 11(1): 62-67.

Tseng, S.H., Lo, Y.W., Chang, P.C., Chou, S.S. \& Chang, H.M. 2004. Simultaneous quantification of glyphosate, glufosinate, and their major metabolites in rice and soybean sprouts by gas chromatography with pulsed flame photometric detector. J. Agric. Food Chem. 52(13): 4057-4063.

Tsuji, M., Akiyama, Y. \& Yano, M. 1997. Simultaneous determination of glufosinate and glyphosate in crops. Analytical Sciences 13(2): 283-285.

Weber, J., Wilkerson, G. \& Reinhardt, C. 2004. Calculating pesticide sorption coefficients $(\mathrm{Kd})$ using selected soil properties. Chemosphere 55: 157-166.

You, W. \& Barker, A.V. 2007. Effects of soil-applied glufosinateammonium on tomato plant growth and ammonium accumulation. Commun. Soil Sci. Plant Anal. 35(13-14): 1945-1955.

You, W. \& Barker, A.V. 2002. Herbicidal actions of root-applied glufosinate ammonium on tomato plants. J. Am. Soc. Hortic. Sci. 127(2): 200-204

Yun, Z., Kai, W., Wu, J. \& Zhang, H. 2014. Field dissipation and storage stability of glufosinate ammonium and its metabolites in soil. Int. J. Environ. Anal. Chem. 2014: 256091.

Zablotowicz, R., Krutz, L., Weaver, M.A., Accinelli, C. \& Reddy, K.N. 2008. Glufosinate and ammonium sulfate inhibit atrazine degradation in adapted soils. Biol. Fert. Soils 45(1): 19-26

Centre for Earth Sciences and Environment Faculty of Science and Technology Universiti Kebangsaan Malaysia 43600 UKM Bangi, Selangor Darul Ehsan Malaysia

*Corresponding author; email: mardiana@ukm.edu.my

Received: 4 September 2019

Accepted: 3 October 2019 